\title{
Labour Induction with Misoprostol in German Obstetric Clinics: What Are the Facts on Such Use?
}

\author{
Anwendung von Misoprostol zur Geburtseinleitung an \\ deutschen Geburtskliniken: Was wird wirklich gemacht?
}

(c) (9) $\ominus$

Authors

Sven Kehl ${ }^{1}$, Christel Weiss ${ }^{2}$, Werner Rath ${ }^{3}$, Michael Schneider ${ }^{1}$, Florian Stumpfe ${ }^{1}$, Florian Faschingbauer ${ }^{1}$, Matthias W. Beckmann ${ }^{1}$, Patrick Stelzl ${ }^{1,4}$

Affiliations

1 Frauenklinik, Universitätsklinikum Erlangen, Erlangen, Germany

2 Abteilung für Medizinische Statistik, Biomathematik und Informationsverarbeitung, Medizinische Fakultät Mannheim, Universität Heidelberg, Mannheim, Germany

3 Medizinische Fakultät, Gynäkologie und Geburtshilfe, Universitätsklinikum Schleswig-Holstein, Campus Kiel, Kiel, Germany

4 Abteilung für Gynäkologie, Geburtshilfe und Gynäkologische Endokrinologie, Kepler Universitätsklinikum Linz, Linz, Austria

Key words

misoprostol, labour induction, Cytotec

Schlüsselwörter

Misoprostol, Geburtseinleitung, Cytotec

received

accepted after revision

Bibliography

Geburtsh Frauenheilk 2021; 81: 955-965

DOI 10.1055/a-1538-2200

ISSN 0016-5751

(C) 2021. The Author(s).

This is an open access article published by Thieme under the terms of the Creative Commons Attribution-NonDerivative-NonCommercial-License, permitting copying and reproduction so long as the original work is given appropriate credit. Contents may not be used for commercial purposes, or adapted, remixed, transformed or built upon. (https://creativecommons.org/licenses/by-nc-nd/4.0/)

Georg Thieme Verlag KG, Rüdigerstraße 14,

70469 Stuttgart, Germany

Correspondence

Prof. Dr. med. habil. Sven Kehl

Universitätsklinikum Erlangen, Frauenklinik

Universitätsstraße 21-23, 91054 Erlangen, Germany

sven.kehl@gmail.com
Correspondence

DDr. Patrick Stelzl

Abteilung für Gynäkologie, Geburtshilfe und Gynäkologische Endokrinologie, Kepler Universitätsklinikum Linz

Altenberger Strasse 69, 4040 Linz, Austria

patrick.stelzl@kepleruniklinikum.at

$\Theta$ Deutsche Version unter: https://doi.org/10.1055/a-1538-2200

\section{ABSTRACT}

Subject While the synthetic prostaglandin E1 analogue misoprostol is the most effect labour induction agent, its use is offlabel for the most part. For this reason, and in view of its potential adverse effects and varying approaches to its administration, the drug has recently once again become a focus of critical attention. The objective of this survey was thus to establish a record of labour induction with misoprostol in German clinics and determine the impact of the negative reporting on everyday obstetric practice.

Material and Methods In this cross-sectional study, 635 obstetrics and gynaecology departments in Germany were requested by email to participate in our survey in February/ March 2020. Online responses to 19 questions were requested regarding the clinic, use of misoprostol before and after the critical reporting, use of misoprostol (sourcing, method of administration, dosage, monitoring) and other labour induction methods.

Results A total of 262 (41.3\%) of the clinics solicited for the survey completed the questionnaire. There were no differences regarding the care level (Perinatal Centre Level I, Perinatal Centre Level II, Clinic with Perinatal Focus or Obstetric/Private Clinic; $p=0.2104$ ) or birth counts $(p=0.1845)$. In most cases, misoprostol was prepared in the clinic's own pharmacy (54\%) or imported from another country (46\%) and administered orally in tablet form (95\%). Misoprostol dosage levels varied $(25 \mu \mathrm{g}$ [48\%], $50 \mu \mathrm{g}$ [83\%], $75 \mu \mathrm{g}$ [6\%], $100 \mu \mathrm{g}$ [47\%] and $>100 \mu \mathrm{g}[5 \%])$. Most of the clinics used premanufactured tablets/capsules (59\%), although Cytotec tablets were also di- 
vided $(35 \%)$ or dissolved in water $(5 \%)$. Misoprostol administration intervals were mainly every 4 hours (64\%) or every 6 hours (30\%). CTG checks were run in most cases before and after administration of a dose of misoprostol $(78 \%$ and $76 \%$ ) and before and after administration of a dose of prostaglandin E2 (both $88 \%$ ). Presence of contractions led to no misoprostol (59\%) or no prostaglandin E2 (64\%) being administered in most cases. The critical reporting resulted in discontinuation of use of misoprostol in $17 \%$ of the clinics - mainly smaller obstetric/private clinics with fewer than 1000 births. Labour cocktails were used mainly in obstetric and private clinics (61\%).

Conclusion Misoprostol is an established agent for labour induction in German clinics. The dosing schemes used vary. Improvements of currently common management practices are required, especially in the area of labour induction (CTG checks before and after administration of labour-inducing medication, no administration of prostaglandin if contractions are ongoing). The discussion of use of misoprostol in the media resulted in stoppage of its use mainly in smaller clinics.

\section{ZUSAMMENFASSUNG}

Fragestellung Das synthetische Prostaglandin-E1-Analogon Misoprostol ist das effektivste Medikament zur Geburtseinleitung, wobei es meist im Off-Label-Use angewendet wird. Aus diesem Grund sowie wegen seiner potenziellen Nebenwirkungen und der unterschiedlichen Anwendung stand es zuletzt wieder in der Diskussion. Ziel dieser Umfrage war daher die Erhebung der Anwendung von Misoprostol zur Geburtseinleitung an deutschen Kliniken sowie des Einflusses, den die negative Berichterstattung auf den geburtshilflichen Alltag hatte.

Material und Methodik Im Rahmen dieser Querschnittstudie wurden 635 Abteilungen für Geburtshilfe und Gynäkologie in Deutschland angeschrieben und gebeten, im Februar/ März 2020 an dieser Umfrage teilzunehmen. Es sollten insgesamt 19 Fragen zur Klinik, Verwendung von Misoprostol vor und nach der kritischen Berichterstattung, Anwendung von Misoprostol (Bezug, Applikationsart, Dosierung, Überwachung) und anderen Einleitungsmethoden online beantworten werden.

Ergebnisse Insgesamt komplettierten 262 (41,3\%) der angeschriebenen Kliniken den Fragebogen. Es gab keinen Unterschied bezüglich der Versorgungsstufe (Perinatalzentrum Level I, Perinatalzentrum Level II, Perinataler Schwerpunkt oder Geburtsklinik/Belegklinik; $p=0,2104$ ) und der Anzahl der Geburten $(p=0,1845)$. Meist wurde Misoprostol in der eigenen Apotheke hergestellt (54\%) oder aus dem Ausland importiert (46\%) und oral als Tablette (95\%) verabreicht. Es kamen verschiedene Misoprostol-Dosierungen zum Einsatz $(25 \mu \mathrm{g}$ [48\%], $50 \mu \mathrm{g}$ [83\%], $75 \mu \mathrm{g}$ [6\%], $100 \mu \mathrm{g}$ [47\%] und >100 $\mu \mathrm{g}$ [5\%]). Die meisten Kliniken verwendeten vorgefertigte Tabletten/Kapseln (59\%), jedoch wurden auch Cytotec-Tabletten geteilt (35\%) oder in Wasser aufgelöst (5\%). Die MisoprostolGaben erfolgten vor allem in 4-stündigen (64\%) oder 6-stündigen Intervallen (30\%). Eine CTG-Kontrolle vor und nach einer Misoprostol-Gabe (78\% und 76\%) bzw. einer Prostaglandin-E2-Gabe (jeweils $88 \%$ ) wurde meist durchgeführt. Im Falle von Kontraktionen wurde überwiegend kein Misoprostol (59\%) oder kein Prostaglandin E2 (64\%) verabreicht. Die kritische Berichterstattung führte dazu, dass in $17 \%$ der Kliniken, vor allem kleinere Geburtskliniken/Belegkliniken mit weniger als 1000 Geburten, kein Misoprostol mehr verwendet wurde. Wehencocktails kamen vor allem in Geburts- und Belegkliniken zum Einsatz (61\%).

Schlussfolgerung Misoprostol zur Geburtseinleitung ist in deutschen Kliniken etabliert. Es kommen verschiedene Dosierungsschemata zum Einsatz. Insbesondere das derzeit übliche Management im Rahmen der Geburtseinleitung (CTG-Kontrolle vor und nach einer medikamentösen Geburtseinleitung, keine Prostaglandin-Gabe bei Wehentätigkeit) sollte jedoch verbessert werden. Die mediale Diskussion um die Verwendung von Misoprostol hat dazu geführt, dass vor allem kleinere Kliniken auf Misoprostol verzichten haben.

\section{Introduction}

The past 10 years have seen publication of nearly a dozen metaanalyses on use of misoprostol for labour induction and its efficacy and safety compared to oxytocin, dinoprostone and balloon catheters [1 - 10]. Misoprostol can be administered both vaginally and orally and is considered the most effective labour induction agent in cases of immature cervix [2,3]. Like all medicinal products (prostaglandin E2, oxytocin), misoprostol may also cause overstimulations resulting in changes in the CTG pattern. The risk of an overstimulation is increased in particular with vaginal administration and at higher dosage levels $[3,5,11,12]$. Use of misoprostol for labour induction in women with prior caesarean sections is not recommended [13-16]. The main reason for this is that the sole randomized, controlled study (comparison of vaginal misoprostol versus oxytocin) was prematurely discontinued fol- lowing the occurrence of two uterus ruptures and recruitment of 17 patients [17]. There are also mainly retrospective studies in which misoprostol was administered only vaginally using various dosages and intervals $[18,19]$. According to a Cochrane analysis, not a single uterus rupture occurred following oral administration of misoprostol in 158 pregnant women [20]. Notwithstanding the fact that misoprostol has now been authorized in various countries for labour induction, discussions of this theme arise repeatedly in German-speaking countries, where it is/was only authorized for prevention and treatment of gastroduodenal ulcers, but not for labour induction. Recent articles in the German press have discussed the legality of use of misoprostol for labour induction as a hot button issue with a focus on the lack of marketing authorization, lack of recommendations on dosage and use and potential associations with complications (e.g. overstimulations, pathological CTG, poor child outcomes) [21]. It is indeed not known how 
often misoprostol is used for labour induction in German clinics, with data also lacking on how the drug is prepared, administered and dosed. The last survey from 2013 revealed that many different regimens were in use [22].

The objective of this survey was thus to establish a record of labour induction with misoprostol in German clinics and determine the impact of the negative reporting on everyday obstetric practice.

\section{Material and Methods}

\section{Participants and setting}

In this cross-sectional study, invitations were extended to 635 obstetrics and gynaecology departments in Germany. The respective department heads were provided with a link to the questionnaire in an email together with a cover letter explaining the objective and design of the study. The questionnaire was developed based on national and international recommendations and guidelines. To ensure clarity and feasibility, the questionnaire was pre-tested by three experienced obstetricians who had not contributed to development of the survey. Modifications were made based on the resulting feedback. The results of these pre-tests were not taken into account in the final data evaluation. The final questionnaire comprised a total of 19 multiple choice and open questions covering the following topics:

- Demographic aspects of the respective obstetric units (3 questions)

- Use of misoprostol before and after current discussion (3 questions)

- Misoprostol sourcing (1 question)

- Misoprostol administration (6 questions)

- Misoprostol dosage schemes (2 questions)

- Clinic-specific labour induction management (1 question)

- Clinic-specific labour induction alternatives (3 questions)

The survey was conducted pseudonymously. A maximum of two reminders were sent out 14 and 21 days after the first invitation to participate. No personal data were recorded.

\section{Data collection}

Data were collected from 24 February to 20 March 2020 on a voluntary basis with no remuneration of the participating clinics. An online survey format was chosen to facilitate Germany-wide participation. The participation link was available at www.soscisurvey.de (source: Stelzl P, Survey [Version 3.2.14i], https://www.soscisurvey.de, accessed 20 December 2020). This online platform ensured a high level of data protection because the IP addresses of the participating clinics were not recorded. Each participant was allowed to fill out the questionnaire just once during the 26-day survey period. To ensure complete responses, a warning message reminded participants to furnish missing responses before they could access the next page of the survey. A total of 262 of the 635 solicited clinics completed the questionnaire for a response rate of $41.3 \%$. At the end of the survey period, the collected data were exported to an Excel table and forwarded for statistical analysis.

\section{Statistical analysis}

All statistical calculations and analyses were done with the statistics program package SAS, Release 9.4 (SAS Institute Inc., Cary, North Carolina, USA). Both absolute and relative frequencies are indicated for all responses to the multiple choice questions. To compare two or more groups, an $x^{2}$ test was used or (if the conditions for that test type were not met) a Fisher's exact test. The Mann-Whitney $U$ test, or for more than two groups the KruskalWallis test, was used for ordinal scale characteristics. Missing values or responses such as "don't know" were not considered for the analyses. A multiple logistic regression analysis was performed for each outcome to determine which combination of impact parameters (medical care level, births per year, labour induction rate) provided the best explanation for the respective outcome. Generally speaking, a test result was considered significant if the $p$ value was below 0.05 . A significance level of 0.10 was assumed for the multiple regression analyses to render the combined impact of multiple factors more recognizable.

\section{Results}

- Table 1 presents the demographic parameters of the clinics that either used or did not use misoprostol in Cytotec prior to the critical reporting. There was no statistically significant difference in use of misoprostol between the different care levels (Perinatal Centre Level I, Perinatal Centre Level II, Clinic with Perinatal Focus or Obstetric/Private Clinic; $p=0.2104$ ). Use of the substance was also independent of the number of births $(p=0.1845)$. A trend towards significance was seen in the impact of the labour induction rate $(p=0.0518)$. It was observed that misoprostol was used particularly often in clinics with moderate labour induction rates of between 20 and $30 \%$.

\section{Sourcing and method of administration of misoprostol}

Sourcing and administration of misoprostol varied in the different clinics as shown in - Table 2. Misoprostol was prepared in the clinic pharmacy in about half of the cases (54\%) or imported from other countries (46\%). These figures did not differ amongst the different care levels $(p=0.8185)$. Sourcing of the agent did not correlate with either number of births per year or labour induction rate $(p=0.8398 / p=0.8795$, $>$ Tables 8 and $\mathbf{9})$.

Misoprostol was administered orally in tablet form in nearly all clinics (95\%) ( $>$ Table 2). It was additionally administered vaginally in tablet form in one clinic in four (25\%), and more rarely in the form of inserts (12\%). Administration of misoprostol dissolved in liquid for drinking was practised in only a few clinics (5\%).

\section{Dosage of misoprostol}

Dosage of misoprostol varied in the different clinics. Generally speaking, dosage levels of $50 \mu \mathrm{g}$ and above were used in most clinics $(89 \%)$ independent of medical care level $(p=0.2192)$. Misoprostol dosage levels of $25 \mu \mathrm{g}(48 \%), 50 \mu \mathrm{g}(83 \%), 75 \mu \mathrm{g}(6 \%)$, $100 \mu \mathrm{g}(47 \%)$ and $>100 \mu \mathrm{g}(5 \%)$ were used, whereby low doses of $25 \mathrm{\mu g}$ were administered mainly in perinatal centres and higher doses of $100 \mu \mathrm{g}$ were administered with notable frequency in obstetric clinics $(p=0.0175 / p=0.0183)$. In most clinics, the dosage 
- Table 1 Comparison of the misoprostol subgroups in terms of demographic parameters. Percentages refer to the subgroup named in the respective table header.

\begin{tabular}{|c|c|c|c|}
\hline & Misoprostol $(n=221,84 \%)$ & No misoprostol $(n=41,16 \%)$ & p values \\
\hline Perinatal Centre Level I & $76(89 \%)$ & $9(11 \%)$ & \multirow[t]{4}{*}{0.2104} \\
\hline Perinatal Centre Level II & $20(77 \%)$ & $6(23 \%)$ & \\
\hline Clinic with Perinatal Focus & $38(78 \%)$ & $11(22 \%)$ & \\
\hline Obstetric/Private Clinic & $87(85 \%)$ & $15(15 \%)$ & \\
\hline \multicolumn{3}{|l|}{ Births per year } & \multirow[t]{7}{*}{0.1845} \\
\hline . $<500$ & $16(94 \%)$ & $1(6 \%)$ & \\
\hline . 500-999 & $72(78 \%)$ & $20(22 \%)$ & \\
\hline . 1000-1499 & $49(84 \%)$ & $9(16 \%)$ & \\
\hline . 1500-1999 & $42(86 \%)$ & $7(14 \%)$ & \\
\hline - 2000-3000 & $27(90 \%)$ & $3(10 \%)$ & \\
\hline . $>3000$ & $15(94 \%)$ & $1(6 \%)$ & \\
\hline \multicolumn{3}{|l|}{ Labour induction rate } & \multirow[t]{4}{*}{0.0518} \\
\hline . $<20 \%$ & $69(78 \%)$ & $20(22 \%)$ & \\
\hline - $20-30 \%$ & $143(88 \%)$ & $19(12 \%)$ & \\
\hline$=30 \%$ & $9(82 \%)$ & $2(18 \%)$ & \\
\hline
\end{tabular}

forms were delivered prefabricated as tablets/capsules (58\%). In the other cases, the Cytotec tablet was divided (35\%) or dissolved in water (5\%).

In most cases, misoprostol was administered every four hours (63\%) or every six hours (30\%), more rarely every two hours (7\%) or at other intervals (4\%). In Level 2 Perinatal Centres, misoprostol was administered more frequently, i.e. every two hours or, more rarely, every four hours $(p=0.0316 / p=0.0113)$. Depending on the dosage interval used, in most cases three (49\%), four (30\%) or two (12\%) doses were administered per day. Use of misoprostol only was reported for two (47\%) or three (39\%) successive days, rarely for more than three days (9\%) or for only one day (5\%).

An initial dose of $50 \mu \mathrm{g}(55 \%)$ or $25 \mu \mathrm{g}(45 \%)$ was selected in nearly all clinics. The initial dose was $100 \mu \mathrm{g}$ in one clinic only. The decision by a given clinic to begin with a dose of at least $50 \mu \mathrm{g}$ was found to be independent of the respective medical care level ( $p=0.1129$ ); number of births and rate of labour inductions also did not influence this decision $(p=0.6025 / p=0.3922$, $>$ Tables 8 and 9 ).

\section{Impact of media reporting on use of misoprostol}

- Table 3 shows the impact of the critical reporting on use of misoprostol. Use of misoprostol was discontinued in $17 \%$ of the clinics. This was independent of medical care level $(p=0.9436)$ and labour induction rate $(p=0.2388$, > Table 9$)$. It was, however, observed that a high percentage (about $60 \%$ ) of clinics with fewer than 1000 births per year discontinued use of misoprostol following the reporting $(p=0.0537$, $>$ Table 8$)$. The main reasons for this were worry about patient reactions, avoidance of having to justify decisions and fear of legal consequences (40\% in each of these categories). In $31 \%$ of the clinics, further use was disallowed by the boss or clinic management. Changes were also instituted in the clinics that continued using misoprostol: Increased efforts to provide information characterized the main change (80\% of cases), with only a few cases of a different induction scheme (6\%) or a lower initial dose for induction (4\%) being introduced.

\section{Management for labour induction}

Management of misoprostol use for labour induction is presented in $>$ Table 4. Written information was provided regarding the offlabel use of misoprostol in $81 \%$ of cases. In cases of labour induction post prior caesarean section - regardless of the method used - written information was provided in only $24 \%$ of the clinics. Labour induction is an inpatient procedure in almost all such cases (97\%). Medical labour induction is almost always carried out accompanied by CTG checks: This was done in $78 \%$ and $88 \%$ of the participating clinics before administration of misoprostol and prostaglandin E2 respectively. CTG checks were performed just as frequently after administration of a dose of misoprostol (76\%) and prostaglandin E2 (88\%). Cases in which no CTG check was performed before or after administration of a dose of prostaglandin showed no dependence on medical care level, number of births or labour induction rate $(p=0.8414, p=0.9677$, $p=0.5527)$. No misoprostol was administered in the presence of contractions in 146 clinics (59\%). 159 clinics (64\%) also administered no prostaglandin E2 if labour contractions were present.

Differences between the clinics were seen in particular regarding the use of labour cocktails (outpatient or inpatient) $(p=0.0006)$ : Their administration is comparatively frequent $(61 \%)$ in obstetric clinics.

\section{Alternative methods of labour induction}

Alternative methods of labour induction in cases of immature cervix (Bishop Score <3) are presented in > Table 5. Frequent inpatient approaches in this situation are prostaglandin E2 (vaginal $84 \%$, or cervical $56 \%$ ) and balloon catheter (53\%). Balloon cathe- 
- Table 2 Comparison of medical care levels in terms of use of misoprostol prior to reporting. Percentages refer to the care level indicated in the respective table header.

\begin{tabular}{|c|c|c|c|c|c|c|}
\hline & $\begin{array}{l}\text { Total } \\
(\mathrm{n}=221)\end{array}$ & $\begin{array}{l}\text { PNC Level } \\
\text { I }(n=76)\end{array}$ & $\begin{array}{l}\text { PNC Level } \\
\text { II }(n=20)\end{array}$ & $\begin{array}{l}\text { Clinic with Perina- } \\
\text { tal Focus }(\mathrm{n}=38)\end{array}$ & $\begin{array}{l}\text { Obstetric/Private } \\
\text { Clinic }(n=87)\end{array}$ & p values \\
\hline \multicolumn{7}{|c|}{ What was your source for misoprostol? } \\
\hline Preparation in clinic pharmacy & $111(54 \%)$ & $41(56 \%)$ & $11(58 \%)$ & $17(47 \%)$ & $42(53 \%)$ & \multirow[t]{2}{*}{0.8185} \\
\hline Import from other country & $96(46 \%)$ & $32(44 \%)$ & $8(42 \%)$ & $19(53 \%)$ & $37(47 \%)$ & \\
\hline \multicolumn{7}{|c|}{ What method(s) of administration did you use?* } \\
\hline Oral (tablet) & $209(95 \%)$ & $73(96 \%)$ & $20(100 \%)$ & $35(92 \%)$ & $81(93 \%)$ & 0.5806 \\
\hline Oral (liquid) & $11(5 \%)$ & $3(4 \%)$ & $1(5 \%)$ & $2(5 \%)$ & $5(6 \%)$ & 0.9664 \\
\hline Vaginal (tablet) & $56(25 \%)$ & $22(29 \%)$ & $3(15 \%)$ & $9(24 \%)$ & $22(25 \%)$ & 0.6351 \\
\hline Vaginal (insert) & $26(12 \%)$ & $13(17 \%)$ & $2(10 \%)$ & $4(11 \%)$ & $7(8 \%)$ & 0.3660 \\
\hline \multicolumn{7}{|l|}{ What dosage levels were used?* } \\
\hline $25 \mu \mathrm{g}$ & $106(48 \%)$ & $45(59 \%)$ & $12(60 \%)$ & $12(32 \%)$ & $37(43 \%)$ & 0.0175 \\
\hline $50 \mu g$ & $183(83 \%)$ & $67(88 \%)$ & $13(65 \%)$ & $33(87 \%)$ & $70(80 \%)$ & 0.0802 \\
\hline $75 \mu \mathrm{g}$ & $14(6 \%)$ & $7(9 \%)$ & 0 & $1(3 \%)$ & $6(7 \%)$ & 0.4763 \\
\hline $100 \mu \mathrm{g}$ & $104(47 \%)$ & $38(50 \%)$ & $4(20 \%)$ & $14(37 \%)$ & $48(55 \%)$ & 0.0183 \\
\hline$>100 \mu \mathrm{g}$ & $11(5 \%)$ & $5(7 \%)$ & $2(10 \%)$ & $2(5 \%)$ & $2(2 \%)$ & 0.2966 \\
\hline \multicolumn{7}{|c|}{ Were dosage levels of $50 \mu \mathrm{g}$ and more in general use? } \\
\hline Yes & $196(89 \%)$ & $70(92 \%)$ & $15(75 \%)$ & $34(89 \%)$ & $77(89 \%)$ & \multirow[t]{2}{*}{0.2192} \\
\hline No & $25(11 \%)$ & $6(8 \%)$ & $5(25 \%)$ & $4(11 \%)$ & $10(11 \%)$ & \\
\hline \multicolumn{7}{|c|}{ How did you obtain the desired dosage form? } \\
\hline Capsule/tablet dosed accordingly & $129(59 \%)$ & $46(61 \%)$ & $15(75 \%)$ & $20(53 \%)$ & $48(57 \%)$ & \multirow[t]{4}{*}{0.7987} \\
\hline Division of tablet & $77(35 \%)$ & $25(33 \%)$ & $5(25 \%)$ & $16(42 \%)$ & $31(37 \%)$ & \\
\hline $\begin{array}{l}\text { Dissolution of tablet plus liquid } \\
\text { in appropriate amount }\end{array}$ & $11(5 \%)$ & $4(5 \%)$ & 0 & $2(5 \%)$ & $5(6 \%)$ & \\
\hline Other & 0 & 0 & 0 & 0 & 0 & \\
\hline \multicolumn{7}{|c|}{ What dosing intervals were used for misoprostol?* } \\
\hline Every 2 hours & $16(7 \%)$ & $3(4 \%)$ & $5(25 \%)$ & $2(5 \%)$ & $6(7 \%)$ & 0.0316 \\
\hline Every 4 hours & $139(64 \%)$ & $50(66 \%)$ & $6(30 \%)$ & $26(68 \%)$ & $57(66 \%)$ & 0.0113 \\
\hline Every 6 hours & $66(30 \%)$ & $26(34 \%)$ & $7(35 \%)$ & $10(26 \%)$ & $23(26 \%)$ & 0.7124 \\
\hline Other & $8(4 \%)$ & $1(1 \%)$ & $2(10 \%)$ & 0 & $5(6 \%)$ & 0.1064 \\
\hline \multicolumn{7}{|c|}{ How many doses of misoprostol were administered per patient and day? } \\
\hline One & $2(1 \%)$ & 0 & $1(5 \%)$ & 0 & $1(1 \%)$ & \multirow[t]{7}{*}{0.4921} \\
\hline Two & $27(12 \%)$ & $7(9 \%)$ & $3(15 \%)$ & $8(22 \%)$ & $9(11 \%)$ & \\
\hline Three & $107(49 \%)$ & $37(49 \%)$ & $9(45 \%)$ & $17(46 \%)$ & $44(52 \%)$ & \\
\hline Four & $65(30 \%)$ & $26(34 \%)$ & $4(20 \%)$ & $10(27 \%)$ & $25(29 \%)$ & \\
\hline Five & $6(3 \%)$ & $3(4 \%)$ & 0 & $1(3 \%)$ & $2(2 \%)$ & \\
\hline Six & $8(4 \%)$ & $2(3 \%)$ & $2(10 \%)$ & $1(3 \%)$ & $3(4 \%)$ & \\
\hline More than six & $3(1 \%)$ & $1(1 \%)$ & $1(5 \%)$ & 0 & $1(1 \%)$ & \\
\hline \multicolumn{7}{|c|}{ On how many successive days was (only) misoprostol used for labour induction? } \\
\hline 1 day & $11(5 \%)$ & $3(4 \%)$ & $1(5 \%)$ & $2(5 \%)$ & $5(6 \%)$ & \multirow[t]{4}{*}{0.0078} \\
\hline 2 days & $103(47 \%)$ & $26(34 \%)$ & $11(55 \%)$ & $23(62 \%)$ & $43(51 \%)$ & \\
\hline 3 days & $84(39 \%)$ & $34(45 \%)$ & $8(40 \%)$ & $9(24 \%)$ & $33(39 \%)$ & \\
\hline$>3$ days & $20(9 \%)$ & $13(17 \%)$ & 0 & $3(8 \%)$ & $4(5 \%)$ & \\
\hline \multicolumn{7}{|c|}{ What is the substance amount for the initial dose? } \\
\hline $25 \mu \mathrm{g}$ & $90(45 \%)$ & $36(51 \%)$ & $11(61 \%)$ & $12(35 \%)$ & $31(39 \%)$ & \multirow[t]{3}{*}{$0.1129^{* *}$} \\
\hline $50 \mu \mathrm{g}$ & $110(55 \%)$ & $33(47 \%)$ & $7(39 \%)$ & $22(63 \%)$ & $48(61 \%)$ & \\
\hline $100 \mu \mathrm{g}$ & $1(0.5 \%)$ & $1(1 \%)$ & 0 & 0 & 0 & \\
\hline
\end{tabular}


- Table 3 Comparison of medical care levels in terms of use of misoprostol following critical reporting. Percentages refer to the care level indicated in the respective table header.

\begin{tabular}{|c|c|c|c|c|c|c|}
\hline & $\begin{array}{l}\text { Total } \\
(\mathrm{n}=\mathbf{2 1 1})\end{array}$ & $\begin{array}{l}\text { PNC Level } \\
\text { I }(n=73)\end{array}$ & $\begin{array}{l}\text { PNC Level } \\
\text { II }(\mathbf{n}=\mathbf{2 0})\end{array}$ & $\begin{array}{l}\text { Clinic with } \\
\text { Perinatal } \\
\text { Focus }(n=35)\end{array}$ & $\begin{array}{l}\text { Obstetricl } \\
\text { Private Clinic } \\
(n=83)\end{array}$ & $\mathrm{p}$ values \\
\hline \multicolumn{7}{|c|}{ Is use of misoprostol continuing subsequent to the critical reporting? } \\
\hline Yes & $176(83 \%)$ & $61(84 \%)$ & $17(85 \%)$ & $28(80 \%)$ & $70(84 \%)$ & \multirow[t]{2}{*}{0.9436} \\
\hline No & $35(17 \%)$ & $12(16 \%)$ & $3(15 \%)$ & $7(20 \%)$ & $13(16 \%)$ & \\
\hline \multicolumn{7}{|l|}{ What has changed? } \\
\hline We have discontinued its use $(n=35), \ldots{ }^{*}$ & & $(n=12)$ & $(n=3)$ & $(n=7)$ & $(n=13)$ & \\
\hline $\begin{array}{l}\text {... because it was disallowed } \\
\text { (boss/clinic management/...) }\end{array}$ & $11(31 \%)$ & $4(33 \%)$ & $2(67 \%)$ & $1(14 \%)$ & $4(31 \%)$ & 0.4963 \\
\hline ... because we fear legal consequences & $14(40 \%)$ & $2(17 \%)$ & $1(33 \%)$ & $4(57 \%)$ & $7(54 \%)$ & 0.1936 \\
\hline $\begin{array}{l}\text {... to avoid having to justify decisions to patients, } \\
\text { due to worry about patient reactions, }\end{array}$ & $14(40 \%)$ & $7(58 \%)$ & $1(33 \%)$ & $3(43 \%)$ & $3(23 \%)$ & 0.3404 \\
\hline We have continued its use $(n=176) \ldots{ }^{*}$ & & $(n=61)$ & $(n=17)$ & $(n=28)$ & $(n=70)$ & \\
\hline ... in lower single doses & $7(4 \%)$ & $1(2 \%)$ & $1(6 \%)$ & $1(4 \%)$ & $4(6 \%)$ & 0.5116 \\
\hline $\begin{array}{l}\text {... with a different treatment scheme } \\
\text { (lower total dose) }\end{array}$ & $10(6 \%)$ & $4(7 \%)$ & $1(6 \%)$ & $2(7 \%)$ & $3(4 \%)$ & 0.8932 \\
\hline $\begin{array}{l}\text {... as before, but we must increase efforts to provide } \\
\text { information }\end{array}$ & $141(80 \%)$ & $51(84 \%)$ & $12(71 \%)$ & $23(82 \%)$ & $55(9 \%)$ & 0.6566 \\
\hline Other & $39(22 \%)$ & $12(20 \%)$ & $5(29 \%)$ & $5(18 \%)$ & $17(24 \%)$ & 0.7479 \\
\hline
\end{tabular}

ters are used most frequently in Level I Perinatal Centres (77\%) and infrequently in Clinics with Perinatal Focus (34\%, p < 0.0001). Further options include dilapan (38\%), labour cocktail (35\%) and even oxytocin (29\%). Outpatient management covering a variety of methods is only rarely offered (in fewer than $10 \%$ of the clinics).

Oxytocin (85\%), vaginal prostaglandin E2 (73\%) and labour cocktail (39\%) are most frequently selected for induction when the cervix is mature ( $\triangleright$ Table 6 ). Approaches using cervical prostaglandin E2 (31\%), balloon catheter (24\%) and dilapan (8\%) are also used. Labour cocktails in cases of mature cervix are administered more frequently in obstetric clinics ( $p=0.0431)$.

\section{Labour induction in condition post sectio}

If a patient history includes a caesarean section, the favoured approaches to induction are oxytocin (63\%) and vaginal prostaglandin E2 (61\%) as well as the mechanical methods, balloon catheter (49\%, especially at Level I Perinatal Centres at 73\%) and dilapan (35\%) ( $\triangleright$ Table 7 ). Only $2 \%$ of the clinics generally eschew labour induction in condition post sectio.

Generation of a multiple statistical model using logistic regression analysis was only feasible for the outcome "Use of labour cocktail", whereby the significance level was set at 0.10 . The observation was made that annual birth count $(p<0.0001)$ and medical care level $(p=0.0893)$ impact this parameter independently. For the other parameters (initial dose $50 \mu \mathrm{g}$, use of dosages of $50 \mathrm{\mu g}$ and more, no misoprostol after reporting) a multiple analysis revealed that only a single parameter was significant in each case (whereby the significance level was set at $\alpha=0.10$ ).

\section{Discussion}

$41 \%$ of the 635 clinics solicited for this national survey, which represented different obstetric care levels, completed the questionnaire. It can be assumed that this study provides a representative overview of labour induction as practised in Germany. Misoprostol was used for labour induction in most of the clinics when the survey was conducted. This was true regardless of care level and clinic size. This confirms that misoprostol represents a standard method of medical labour induction.

A survey in 2013 revealed that a majority of clinics (66\%) were already using misoprostol for labour induction at that time [22].

In most cases, misoprostol was prepared in the clinic's own pharmacy (54\%) or imported from another country (45\%) and administered orally in tablet form (95\%). It was also administered vaginally in tablet form in one of four clinics (25\%) and in some clinics in the form of inserts (12\%). However, the misoprostol insert which has marketing authorization is now no longer available.

The desired dosage was ensured with prefabricated tablets/ capsules (59\%). The Cytotec tablet $(200 \mu \mathrm{g})$ was divided $(35 \%)$ or dissolved in water $(5 \%)$ in the remaining cases. This manual division of the Cytotec tablets is an ill-advised procedure now condemned as such by both the current guideline recommendations and a "Red Hand Letter" issued by the Federal Institute for Drugs and Medical Devices (Bundesinstitut für Arzneimittel und Medizinprodukte - BfArM) $[13,15,16,23]$. Despite the WHO recommendation, dissolving the tablet in water should also not be done due to the resulting imprecision as to stability and active pharmaceutical ingredient concentration [24]. 
- Table 4 Comparison of medical care levels in terms of management of misoprostol use for labour induction.

\begin{tabular}{|c|c|c|c|c|c|c|}
\hline & $\begin{array}{l}\text { Total } \\
(n=249)\end{array}$ & $\begin{array}{l}\text { PNC Level } \\
\text { I }(\mathrm{n}=\mathbf{8 1})\end{array}$ & $\begin{array}{l}\text { PNC Level } \\
\text { II }(\mathbf{n}=\mathbf{2 6})\end{array}$ & $\begin{array}{l}\text { Clinic with } \\
\text { Perinatal } \\
\text { Focus }(n=44)\end{array}$ & $\begin{array}{l}\text { Obstetric/ } \\
\text { Private Clinic } \\
(\mathrm{n}=98)\end{array}$ & $\mathrm{p}$ values \\
\hline $\begin{array}{l}\text { Provision of written information on off-label use } \\
\text { when misoprostol is used }\end{array}$ & $202(81 \%)$ & 73 & 18 & 31 & 80 & 0.0188 \\
\hline $\begin{array}{l}\text { Provision of written information on off-label use } \\
\text { when labour is induced post prior caesarean section } \\
\text { (condition post sectio) }\end{array}$ & $60(24 \%)$ & 26 & 8 & 9 & 17 & 0.1010 \\
\hline $\begin{array}{l}\text { Outpatient labour induction with misoprostol } \\
\text { possible }\end{array}$ & $8(3 \%)$ & 2 & 1 & 2 & 3 & 0.8347 \\
\hline CTG check before misoprostol dose & $193(78 \%)$ & 69 & 16 & 29 & 79 & 0.0149 \\
\hline CTG check before prostaglandin E2 dose & $218(88 \%)$ & 70 & 23 & 40 & 85 & 0.8895 \\
\hline CTG check after misoprostol dose & $189(76 \%)$ & 68 & 15 & 30 & 76 & 0.0272 \\
\hline CTG check after prostaglandin E2 dose & $218(88 \%)$ & 70 & 23 & 41 & 84 & 0.6374 \\
\hline No CTG check before or after prostaglandin dose & $35(14 \%)$ & 11 & 3 & 5 & 16 & 0.8414 \\
\hline No misoprostol dose in the presence of contractions & $146(59 \%)$ & 51 & 14 & 27 & 54 & 0.6798 \\
\hline $\begin{array}{l}\text { No prostaglandin E2 dose in the presence of labour } \\
\text { contractions }\end{array}$ & $159(64 \%)$ & 51 & 16 & 31 & 61 & 0.7943 \\
\hline Raising of oxytocin dose every $10-20$ minutes & $74(30 \%)$ & 19 & 7 & 12 & 36 & 0.2557 \\
\hline Raising of oxytocin dose every $30-60$ minutes & $102(41 \%)$ & 39 & 10 & 15 & 38 & 0.4154 \\
\hline Raising of oxytocin dose at intervals $>60$ minutes & $15(6 \%)$ & 5 & 5 & 2 & 3 & 0.8676 \\
\hline $\begin{array}{l}\text { Raising of oxytocin dose until contractions occur } \\
\text { at } 2-3 \text { minute intervals }\end{array}$ & $22(9 \%)$ & 9 & 1 & 3 & 9 & 0.7609 \\
\hline $\begin{array}{l}\text { Raising of oxytocin dose until contractions occur } \\
\text { at } 4-5 \text { minute intervals }\end{array}$ & $48(19 \%)$ & 16 & 7 & 13 & 12 & 0.0693 \\
\hline $\begin{array}{l}\text { Discontinuation of oxytocin administration } \\
\text { for labour induction after } 5 \text { hours }\end{array}$ & $78(31 \%)$ & 23 & 10 & 10 & 35 & 0.3437 \\
\hline $\begin{array}{l}\text { Discontinuation of oxytocin administration } \\
\text { for labour induction after } 5-10 \text { hours }\end{array}$ & $36(14 \%)$ & 11 & 3 & 10 & 12 & 0.3839 \\
\hline $\begin{array}{l}\text { Discontinuation of oxytocin administration } \\
\text { for labour induction after } 10-15 \text { hours }\end{array}$ & $4(2 \%)$ & 0 & 1 & 2 & 1 & 0.1100 \\
\hline $\begin{array}{l}\text { Discontinuation of oxytocin administration } \\
\text { for labour induction based only on clinical indication } \\
\text { and CTG }\end{array}$ & $82(33 \%)$ & 31 & 4 & 17 & 30 & 0.1353 \\
\hline Castor oil (outpatient or inpatient) & $114(46 \%)$ & 25 & 11 & 18 & 60 & 0.0006 \\
\hline
\end{tabular}

There are no uniform recommendations for misoprostol dosage. $25 \mu \mathrm{g}$ doses are recommended internationally and it is reported that lower dosage levels (up to $50 \mu \mathrm{g}$ ) are associated with outcomes similar to those obtained with higher dosages $(100 \mu \mathrm{g})$ [24]. A further decisive factor in addition to dosage is the route of administration: A very large meta-analysis (611 studies, 31 different methods) confirmed that vaginal misoprostol in a dosage of $\geq 50 \mu \mathrm{g}$ resulted in more cases of overstimulation than placebo (OR 4.40, 95\% Cl 2.22-7.94), but revealed no differences in the rate of transfers to paediatric clinics (OR 0.85 , 95\% Cl 0.57-1.23) [11]. Similar data resulted for oral administration of misoprostol in a dosage of $\geq 50 \mu \mathrm{g}$ per tablet (OR 2.85, 95\% Cl 1.41-5.20 and OR $0.83,95 \% \mathrm{Cl} 0.55-1.20)$. The Swiss Association of Gynaecology and Obstetrics (Schweizerische Gesellschaft für Gynäkologie und Geburtshilfe), in their Expert Brief No. 63 from 2019, recommend dosage levels of $25-50 \mu \mathrm{g}$ vaginally and $20-50 \mu$ orally [13]. The S2k Induction of Labour Guideline describes single doses of 25-
$100 \mu \mathrm{g}$ as possible $[15,16]$. An oral misoprostol preparation slated to become available in Germany this year has received marketing authorization for single doses up to $50 \mu \mathrm{g}$ and a maximum daily dose of $200 \mu \mathrm{g}$. This preparation is already available in Austria [25]. The survey from 2013 revealed that many different regimens were in use [22]. Studies on labour induction with misoprostol in German clinics also revealed a variety of treatment schemes [26-28]. This diversity has remained unchanged: According to the current survey, the misoprostol dosages most frequently used were $25 \mu \mathrm{g}(48 \%), 50 \mu \mathrm{g}(83 \%)$ and $100 \mu \mathrm{g}$ (47\%). Dosages $>100 \mu \mathrm{g}(5 \%)$ were the exception and should be avoided according to current recommendations. The initial dose in nearly all treatment schemes was $50 \mu \mathrm{g}$ or $25 \mu \mathrm{g}$. The interval between doses was in most cases 4 hours (64\%) or 6 hours (30\%), resulting in most cases in three (49\%), four (30\%) or two daily doses $(12 \%)$. Use of the different dosages or intervals was determined to be independent of medical care level. 
- Table 5 Comparison of medical care levels regarding alternatives to misoprostol in cases of immature cervix (Bishop Score 0-3).

\begin{tabular}{|c|c|c|c|c|c|c|}
\hline & $\begin{array}{l}\text { Total } \\
(n=249)\end{array}$ & $\begin{array}{l}\text { PNC Level } \\
\text { I }(n=81)\end{array}$ & $\begin{array}{l}\text { PNC Level } \\
\text { II }(n=26)\end{array}$ & $\begin{array}{l}\text { Clinic with } \\
\text { Perinatal } \\
\text { Focus }(n=44)\end{array}$ & $\begin{array}{l}\text { Obstetric/ } \\
\text { Private Clinic } \\
(n=98)\end{array}$ & p values \\
\hline Dilapan (outpatient) & $19(8 \%)$ & 5 & 4 & 1 & 9 & 0.1975 \\
\hline Dilapan (inpatient) & $94(38 \%)$ & 28 & 11 & 20 & 35 & 0.6013 \\
\hline Balloon catheter (outpatient) & $9(4 \%)$ & 3 & 2 & 1 & 3 & 0.6628 \\
\hline Balloon catheter (inpatient) & $133(53 \%)$ & 62 & 14 & 15 & 42 & $<0.0001$ \\
\hline $\begin{array}{l}\text { Prostaglandin E2/dinoprostone (gel, tablet, insert) } \\
\text { (outpatient) }\end{array}$ & $4(2 \%)$ & 2 & 0 & 1 & 1 & 0.7931 \\
\hline $\begin{array}{l}\text { Prostaglandin E2/dinoprostone (gel, tablet, insert) } \\
\text { (inpatient) }\end{array}$ & $208(84 \%)$ & 66 & 20 & 39 & 83 & 0.5718 \\
\hline $\begin{array}{l}\text { Prostaglandin E2/dinoprostone (cervical gel) } \\
\text { (outpatient) }\end{array}$ & $4(2 \%)$ & 2 & 0 & 1 & 1 & 0.7931 \\
\hline $\begin{array}{l}\text { Prostaglandin E2/dinoprostone (cervical gel) } \\
\text { (inpatient) }\end{array}$ & $140(56 \%)$ & 46 & 16 & 23 & 55 & 0.8991 \\
\hline Oxytocin & $72(29 \%)$ & 23 & 7 & 9 & 33 & 0.4449 \\
\hline Castor oil (outpatient) & $12(5 \%)$ & 5 & 0 & 1 & 6 & 0.5788 \\
\hline Castor oil (inpatient) & $87(35 \%)$ & 16 & 10 & 12 & 49 & 0.0002 \\
\hline Other & $15(6 \%)$ & 3 & 4 & 1 & 7 & 0.1340 \\
\hline
\end{tabular}

- Table 6 Comparison of medical care levels regarding alternatives to misoprostol in cases of mature cervix.

\begin{tabular}{|c|c|c|c|c|c|c|}
\hline & $\begin{array}{l}\text { Total } \\
(n=249)\end{array}$ & $\begin{array}{l}\text { PNC Level } \\
\text { I }(\mathrm{n}=\mathbf{8 1})\end{array}$ & $\begin{array}{l}\text { PNC Level } \\
\text { II }(n=26)\end{array}$ & $\begin{array}{l}\text { Clinic with } \\
\text { Perinatal } \\
\text { Focus }(n=44)\end{array}$ & $\begin{array}{l}\text { Obstetric/ } \\
\text { Private Clinic } \\
(n=98)\end{array}$ & $\mathrm{p}$ values \\
\hline Dilapan (outpatient) & $3(1 \%)$ & 1 & 1 & 0 & 1 & 0.5040 \\
\hline Dilapan (inpatient) & $21(8 \%)$ & 5 & 3 & 6 & 7 & 0.4339 \\
\hline Balloon catheter (outpatient) & $5(2 \%)$ & 1 & 2 & 0 & 2 & 0.2142 \\
\hline Balloon catheter (inpatient) & $59(24 \%)$ & 25 & 4 & 7 & 23 & 0.1891 \\
\hline $\begin{array}{l}\text { Prostaglandin E2/dinoprostone (gel, tablet, insert) } \\
\text { (outpatient) }\end{array}$ & $6(2 \%)$ & 1 & 0 & 2 & 3 & 0.5629 \\
\hline $\begin{array}{l}\text { Prostaglandin E2/dinoprostone (gel, tablet, insert) } \\
\text { (inpatient) }\end{array}$ & $181(73 \%)$ & 60 & 22 & 28 & 71 & 0.2885 \\
\hline $\begin{array}{l}\text { Prostaglandin E2/dinoprostone (cervical gel) } \\
\text { (outpatient) }\end{array}$ & $1(0.4 \%)$ & 0 & 0 & 0 & 1 & 1.0000 \\
\hline $\begin{array}{l}\text { Prostaglandin E2/dinoprostone (cervical gel) } \\
\text { (inpatient) }\end{array}$ & 77 (31\%) & 24 & 6 & 9 & 38 & 0.1166 \\
\hline Oxytocin & $211(85 \%)$ & 69 & 24 & 38 & 80 & 0.5755 \\
\hline Castor oil (outpatient) & $11(4 \%)$ & 2 & 0 & 2 & 7 & 0.3920 \\
\hline Castor oil (inpatient) & $97(39 \%)$ & 23 & 9 & 17 & 48 & 0.0431 \\
\hline Other & $16(6 \%)$ & 3 & 2 & 2 & 9 & 0.4753 \\
\hline
\end{tabular}

Misoprostol use in this context was off-label when the survey was carried out, making provision of appropriate information obligatory. This information was provided in written form as well in $81 \%$ of cases. Provision of such information in written form is generally recommended in cases of off-label use $[13,15,16]$.

Induction of labour with misoprostol was almost always done in an inpatient setting (97\%). Despite this being practised in out- patient settings as well internationally [29] this is discouraged in current recommendations. Medical labour induction should be performed in an inpatient setting under CTG control $[13,15,16]$.

Earlier guidelines, now out of date, recommended dosing of prostaglandins accompanied by CTG checks and not using prostaglandins in the presence of contractions [30]. However, a pre-dosing CTG check was performed in only $78 \%$ of the clinics surveyed 
- Table 7 Comparison of the medical care levels regarding labour induction methods used in condition post sectio caesarea.

\begin{tabular}{|c|c|c|c|c|c|c|}
\hline & $\begin{array}{l}\text { Total } \\
(n=243)\end{array}$ & $\begin{array}{l}\text { PNC Level } \\
\text { I }(\mathbf{n}=\mathbf{8 1})\end{array}$ & $\begin{array}{l}\text { PNC Level } \\
\text { II }(n=26)\end{array}$ & $\begin{array}{l}\text { Clinic with } \\
\text { Perinatal } \\
\text { Focus }(n=42)\end{array}$ & $\begin{array}{l}\text { Obstetricl } \\
\text { Private Clinic } \\
(n=94)\end{array}$ & $\mathrm{p}$ values \\
\hline Dilapan (outpatient) & $6(2 \%)$ & 1 & 0 & 1 & 4 & 0.6422 \\
\hline Dilapan (inpatient) & $86(35 \%)$ & 25 & 13 & 16 & 32 & 0.3391 \\
\hline Balloon catheter (outpatient) & $7(3 \%)$ & 2 & 1 & 1 & 3 & 0.9472 \\
\hline Balloon catheter (inpatient) & $118(49 \%)$ & 59 & 12 & 14 & 33 & $<0.0001$ \\
\hline $\begin{array}{l}\text { Prostaglandin E2/dinoprostone (gel, tablet, insert) } \\
\text { (outpatient) }\end{array}$ & $4(2 \%)$ & 1 & 0 & 1 & 2 & 1.0000 \\
\hline $\begin{array}{l}\text { Prostaglandin E2/dinoprostone (gel, tablet, insert) } \\
\text { (inpatient) }\end{array}$ & $149(61 \%)$ & 48 & 21 & 23 & 57 & 0.1666 \\
\hline $\begin{array}{l}\text { Prostaglandin E2/dinoprostone (cervical gel) } \\
\text { (outpatient) }\end{array}$ & $2(1 \%)$ & 1 & 0 & 0 & 1 & 1.0000 \\
\hline $\begin{array}{l}\text { Prostaglandin E2/dinoprostone (cervical gel) } \\
\text { (inpatient) }\end{array}$ & $65(27 \%)$ & 23 & 6 & 8 & 28 & 0.5713 \\
\hline Oxytocin & $152(63 \%)$ & 49 & 18 & 27 & 58 & 0.8674 \\
\hline Castor oil (outpatient) & $3(1 \%)$ & 0 & 1 & 1 & 1 & 0.2618 \\
\hline Castor oil (inpatient) & $77(32 \%)$ & 19 & 8 & 12 & 38 & 0.1092 \\
\hline Other & $24(10 \%)$ & 8 & 1 & 6 & 9 & 0.6060 \\
\hline
\end{tabular}

when misoprostol was administered and in $88 \%$ when prostaglandin E2 was used. Percentages of CTG checks after dosing of misoprostol and prostaglandin E2 were similar (76\% and 88\%). Also, misoprostol was administered despite the presence of contractions in $41 \%$ of the clinics, which figure was $36 \%$ for prostaglandin E2. This practice must be viewed critically, since prostaglandins can cause overstimulations. CTC checks before and after dosing of prostaglandins, and doing without prostaglandins in the presence of contractions, thus raise the safety level of this medical labour induction practice and should be done $[15,16]$. It turns out that complications associated with misoprostol, and with prostaglandins in general, are not a matter of dosage, but rather of medical labour induction management in the broader sense. This certainly underscores the importance of the information provided in the new S2k Guideline regarding these points.

Labour induction in condition post sectio is associated with a raised risk of uterus rupture, even though the absolute risk level is low. Accordingly, both earlier and current labour induction guidelines characterize labour induction post sectio caesarea as a possible option $[15,16,31,32]$. In the current survey, nearly all clinics reported performing labour induction in this situation (98\%). However, information in written form regarding off-label use with the available methods is provided in only $24 \%$. This aspect could become legally relevant, for which reason provision of this information in written form is recommended $[15,16]$.

The critical reporting on Cytotec led to discontinuation of use of misoprostol for labour induction in $17 \%$ of the clinics. The main reasons for this were worry about patient reactions, avoidance of having to justify decisions and fear of legal consequences $(40 \%$ in each of these categories). In many cases (31\%) further use was disallowed by the boss or clinic management. This is an impressive demonstration of the power of the press to impact obstetric medical care. In smaller clinics in particular, which depend on every single birth, discontinuation of the drug for this indication was observed above all in clinics with fewer than 500 births, but the critical reporting resulted only in increased efforts to provide information accordingly in other clinics (80\%). There were only a small number of cases of shifts to other induction treatment schemes (6\%) or reduction of individual doses (4\%).

This situation should be viewed critically, since one of the alternative methods of labour induction was listed as the labour cocktail. The labour cocktail, for its part, is uniquely guilty of the aspects criticized in the press: It has no marketing authorization and evidence of safety and efficacy are lacking - this despite its use for labour induction over nearly a century [33,34]. The benefit of this method is not evidence-based [35] and adverse effects/ complications are known [36]. The labour cocktail is therefore not recommended for labour induction in international guidelines [37]. This is a plausible consequence in view of the fact that the active pharmaceutical ingredient, ricinoleic acid, achieves its effect on muscle cells in the uterus and intestine via prostaglandin receptors, so that the same potential adverse effects expected with use of misoprostol and prostaglandin E2 apply to it as well. Ricinus oil (castor oil) is therefore only suitable for labour induction in an inpatient setting and within the context of studies [15, $16]$.

Since the labour cocktail is used above all in smaller clinics (Obstetric/Private Clinic, $p=0.0006$ ) with fewer than 1000 births per year and with lower labour induction rates $(<20 \%, p=0.0117)$, the worry is justified that precisely those clinics that decide to discontinue use of misoprostol because of the critical reporting will increasingly turn to use of the labour cocktail [38]. This represents a sacrifice of quality in medical labour induction and puts patients and children at greater risk. 
- Table 8 Dependence of various parameters on annual number of births. The percentages quantify the proportion of clinics for which the header is true in each case.

\begin{tabular}{|c|c|c|c|c|c|c|}
\hline & $\begin{array}{l}\text { Use of dosage } \\
\text { levels of } 50 \mu \mathrm{g} \\
\text { and more }\end{array}$ & $\begin{array}{l}\text { Pharmacy } \\
\text { preparation }\end{array}$ & $\begin{array}{l}\text { Initial dose } \\
50 \mu \mathrm{g}\end{array}$ & $\begin{array}{l}\text { No misoprostol } \\
\text { after reporting }\end{array}$ & $\begin{array}{l}\text { No CTG check } \\
\text { before or after } \\
\text { prostaglandin dose }\end{array}$ & $\begin{array}{l}\text { Use of } \\
\text { castor oil }\end{array}$ \\
\hline Clinics, total & $196(89 \%)$ & $111(54 \%)$ & $110(55 \%)$ & $35(17 \%)$ & $35(14 \%)$ & $114(46 \%)$ \\
\hline \multicolumn{7}{|c|}{ Births per year: } \\
\hline$<500$ & $15(94 \%)$ & $8(57 \%)$ & $6(46 \%)$ & $8(57 \%)$ & $3(20 \%)$ & $8(53 \%)$ \\
\hline 500-999 & $64(89 \%)$ & 37 (55\%) & $41(61 \%)$ & $9(69 \%)$ & $11(13 \%)$ & $55(63 \%)$ \\
\hline 1000-1499 & $43(88 \%)$ & $20(45 \%)$ & $25(53 \%)$ & $7(15 \%)$ & $9(14 \%)$ & $23(41 \%)$ \\
\hline 1500-1999 & $35(83 \%)$ & $25(61 \%)$ & $18(49 \%)$ & $6(15 \%)$ & $7(15 \%)$ & $12(26 \%)$ \\
\hline $2000-3000$ & $25(93 \%)$ & $15(56 \%)$ & $10(43 \%)$ & $4(15 \%)$ & $3(11 \%)$ & $10(36 \%)$ \\
\hline$>3000$ & $14(93 \%)$ & $6(43 \%)$ & $10(71 \%)$ & $1(7 \%)$ & $3(19 \%)$ & $6(38 \%)$ \\
\hline p value & 0.8900 & 0.8398 & 0.6025 & 0.0537 & 0.9677 & 0.0002 \\
\hline
\end{tabular}

- Table 9 Dependence of various parameters on labour induction rate. The percentages quantify the proportion of clinics for which the header is true in each case.

\begin{tabular}{|c|c|c|c|c|c|c|}
\hline & $\begin{array}{l}\text { Use of dosage } \\
\text { levels of } 50 \mu \mathrm{g} \\
\text { and more }\end{array}$ & $\begin{array}{l}\text { Pharmacy } \\
\text { preparation }\end{array}$ & $\begin{array}{l}\text { Initial dose } \\
50 \mu \mathrm{g}\end{array}$ & $\begin{array}{l}\text { No misoprostol } \\
\text { after reporting }\end{array}$ & $\begin{array}{l}\text { No CTG check } \\
\text { before or after } \\
\text { prostaglandin dose }\end{array}$ & $\begin{array}{l}\text { Use of } \\
\text { castor oil }\end{array}$ \\
\hline Total & $196(89 \%)$ & $111(54 \%)$ & $110(55 \%)$ & $35(17 \%)$ & $35(14 \%)$ & $114(46 \%)$ \\
\hline \multicolumn{7}{|l|}{ Rate: } \\
\hline$<20 \%$ & 62 (90\%) & 35 (55\%) & $39(62 \%)$ & $14(21 \%)$ & $10(12 \%)$ & 48 (57\%) \\
\hline $20-30 \%$ & $125(87 \%)$ & $71(53 \%)$ & $64(50 \%)$ & $20(15 \%)$ & $24(16 \%)$ & $63(41 \%)$ \\
\hline$>30 \%$ & $9(100 \%)$ & $5(56 \%)$ & $8(78 \%)$ & $1(11 \%)$ & $1(10 \%)$ & $3(30 \%)$ \\
\hline$p$ value & 0.8900 & 0.8795 & 0.3992 & 0.2388 & 0.5527 & 0.0117 \\
\hline
\end{tabular}

In summary, this survey provides a good current overview of labour induction as practised in German clinics. Other surveys are in some cases dated (from 2013 [22]) or were intended primarily for midwives [38]. Since this study did not aim to determine complication rates, future studies should analyse the spectrum of adverse effects/complications associated with a labour induction, in particular when misoprostol is administered.

\section{Conclusion}

This study demonstrates impressively that misoprostol, and use of prostaglandins generally speaking, represents an established method in Germany. It also points up the need for further improvement of certain procedures (e.g. dosage of misoprostol, monitoring). These imperatives have been known for some time, for which reason development of the S2k Induction of Labour Guideline was initiated, leading to its publication in December 2020. The Guideline will contribute to improvements in the labour induction procedure. Some of the criticism expressed in the media may be justified, but the way it was presented is itself deserving of criticism. It was revealed that the reporting resulted in discontinuation of use of misoprostol mainly in smaller clinics, giving rise to the concern that poorly investigated methods such as ad- ministration of ricinus oil (castor oil) will take its place. This would represent a sacrifice of quality in medical labour induction and put patients and children at greater risk.

\section{Conflict of Interest}

The authors declare that they have no conflict of interest.

References

[1] Ornat L, Alonso-Ventura V, Bueno-Notivol J et al.; Health Outcomes and Systematic Analyses (HOUSSAY) Research Group. Misoprostol combined with cervical single or double balloon catheters versus misoprostol alone for labor induction of singleton pregnancies: a meta-analysis of randomized trials. J Matern Fetal Neonatal Med 2020; 33: 3453-3468

[2] Alfirevic Z, Keeney E, Dowswell T et al. Methods to induce labour: a systematic review, network meta-analysis and cost-effectiveness analysis. BJOG 2016; 123: 1462-1470

[3] Chen W, Xue J, Peprah MK et al. A systematic review and network metaanalysis comparing the use of Foley catheters, misoprostol, and dinoprostone for cervical ripening in the induction of labour. BJOG 2016; 123: 346-354 
[4] Chen W, Xue J, Gaudet L et al. Meta-analysis of Foley catheter plus misoprostol versus misoprostol alone for cervical ripening. Int J Gynaecol Obstet 2015; 129: 193-198

[5] McMaster K, Sanchez-Ramos L, Kaunitz A. Balancing the efficacy and safety of misoprostol: a meta-analysis comparing 25 versus 50 micrograms of intravaginal misoprostol for the induction of labour. BJOG 2015; 122: 468-476

[6] Liu A, Lv J, Hu Y et al. Efficacy and safety of intravaginal misoprostol versus intracervical dinoprostone for labor induction at term: a systematic review and meta-analysis. J Obstet Gynaecol Res 2014; 40: 897-906

[7] Fox NS, Saltzman DH, Roman AS et al. Intravaginal misoprostol versus Foley catheter for labour induction: a meta-analysis. BJOG 2011; 118 : 647-654

[8] Hofmeyr G], Gülmezoglu AM, Pileggi C. Vaginal misoprostol for cervical ripening and induction of labour. Cochrane Database Syst Rev 2010; 2010 (10): CD000941

[9] Austin SC, Sanchez-Ramos L, Adair CD. Labor induction with intravaginal misoprostol compared with the dinoprostone vaginal insert: a systematic review and metaanalysis. Am J Obstet Gynecol 2010; 202: 624.e1$624 . e 9$

[10] Souza AS, Amorim MM, Feitosa FE. Comparison of sublingual versus vaginal misoprostol for the induction of labour: a systematic review. BJOG 2008; 115: 1340-1349

[11] Alfirevic Z, Keeney E, Dowswell T et al. Which method is best for the induction of labour? A systematic review, network meta-analysis and costeffectiveness analysis. Health Technol Assess 2016; 20: 1-584

[12] Rahman H, Pradhan A, Kharka L et al. Comparative evaluation of 50 microgram oral misoprostol and 25 microgram intravaginal misoprostol for induction of labour at term: a randomized trial. J Obstet Gynaecol Can 2013; 35: 408-416

[13] Schweizerische Gesellschaft für Gynäkologie und Geburtshilfe (SGGG). Expertenbrief Nr.63, Misoprostol zur Geburtseinleitung. Accessed February 15, 2021 at: https://www.sggg.ch/fileadmin/user_upload/ 63_Misoprostol_zur_Geburtseinleitung.pdf

[14] American College of Obstetricians and Gynecologists Committee on Obstetric Practice. ACOG Committee Opinion No. 342: induction of labor for vaginal birth after cesarean delivery. Obstet Gynecol 2006; 108: 465-468

[15] Kehl S, Hösli I, Pecks U et al. Induction of labour. Guideline of the German Society of Gynecology and Obstetrics (S2k, AWMF Registry No. 015-088, December 2020). Accessed February 14, 2021 at: https:// www.awmf.org/leitlinien/detail/II/015-088.html

[16] Kehl S, Hösli I, Pecks U et al. Induction of Labour. Guideline of the DGGG, OEGGG and SGGG (S2k, AWMF Registry No. 015-088, December 2020). Geburtshilfe Frauenheilkd 2021; 81: 870-895. doi:10.1055/a-15197713

[17] Wing DA, Lovett K, Paul RH. Disruption of prior uterine incision following misoprostol for labor induction in women with previous cesarean delivery. Obstet Gynecol 1998; 91 (5 Pt 2): 828-830

[18] Ophir E, Odeh M, Hirsch Y et al. Uterine rupture during trial of labor: controversy of induction's methods. Obstet Gynecol Surv 2012; 67: $734-$ 745

[19] Rath W, Tsikouras P. Misoprostol for Labour Induction after Previous Caesarean Section - Forever a "No Go"? Geburtshilfe Frauenheilkd 2015; 75 : 1140-1147

[20] Alfirevic Z, Aflaifel N, Weeks A. Oral misoprostol for induction of labour. Cochrane Database Syst Rev 2014; (6): CD001338
[21] Scharl A, Abou-Dakn M, Kehl S. „Zur Geburt ein Magenmittel“ - ein Lehrstück. Geburtshilfe Frauenheilkd 2020; 80: 480-483

[22] Voigt F, Goecke TW, Najjari L et al. Off-label use of misoprostol for labor induction in Germany: a national survey. Eur J Obstet Gynecol Reprod Biol 2015; 187: 85-89

[23] Rote-Hand-Brief zu Cytotec ${ }^{\circledR}$ (Misoprostol): Risiken im Zusammenhang mit einer Anwendung zur Geburtseinleitung außerhalb der Zulassung („off-label-use“) 2020. Accessed December 20, 2020 at: https://www. bfarm.de/SharedDocs/Risikoinformationen/Pharmakovigilanz/DE/RHB/ 2020/rhb-cytotec.pdf?__blob=publicationFile \&v=5

[24] WHO. WHO Recommendations for Induction of Labour. Geneva: World Health Organization; 2011. Accessed December 13, 2020 at: http:// www.ncbi.nlm.nih.gov/books/NBK131963/

[25] Gebrauchsinformation: Information für Patienten, Angusta ${ }^{\circledR} 25$ Mikrogramm Tabletten. 2020. Accessed April 02, 2021 at: https:// medikamio.com/downloads/drugs/angusta-25-mikrogramm-tabletten. pdf

[26] Henrich W, Dudenhausen JW, Hanel C et al. [Oral misoprostol against vaginal dinoprostone for labor induction at term: a randomized comparison]. Z Geburtshilfe Neonatol 2008; 212: 183-188

[27] Kehl S, Weiss C, Dammer U et al. [Induction of Labour In Growth Restricted and Small for Gestational Age Fetuses - A Historical Cohort Study]. Z Geburtshilfe Neonatol 2019; 223: 40-47

[28] Puhl A, Weiss C, Schneid A et al. [Does Induction of Labor for Preterm Premature Rupture of Membranes at 34 Weeks of Gestation Increase the Risk for Cesarean Section?]. Z Geburtshilfe Neonatol 2020; 224: 269-274

[29] Helmig RB, Hvidman LE. An audit of oral administration of Angusta(R) (misoprostol) 25 microg for induction of labor in 976 consecutive women with a singleton pregnancy in a university hospital in Denmark. Acta Obstet Gynecol Scand 2020; 99: 1396-1402

[30] AWMF-Leitlinie 015/031 (S1). Anwendung von Prostaglandinen in Geburtshilfe und Gynäkologie. 2010. Accessed December 17, 2020 at: https://www.awmf.org/uploads/tx_szleitlinien/015-031_S1_ Anwendung_von_Prostaglandinen_in_Geburtshilfe_und_Gynaekologie _abgelaufen.pdf

[31] RCOG Green-top Guideline No. 45. Birth after previous caesarean birth. October 2015. Accessed December 13, 2020 at: https://www.rcog.org. uk/globalassets/documents/guidelines/gtg_45.pdf

[32] Society of Obstetricians and Gynaecologists of Canada. SOGC clinica practice guidelines. Guidelines for vaginal birth after previous caesarean birth. Number 155 (Replaces guideline Number 147), February 2005. Int J Gynaecol Obstet 2005; 89: 319-331

[33] Holmes OM. Induction of Labor: Using Quinin, Castor Oil, Rupture of Membranes, and Nasal Pituitrin. Cal West Med 1934; 41: 241-244

[34] Nabors GC. Castor oil as an adjunct to induction of labor: critical re-evaluation. Am J Obstet Gynecol 1958; 75: 36-38

[35] Kelly AJ, Kavanagh ], Thomas ]. Castor oil, bath and/or enema for cervica priming and induction of labour. Cochrane Database Syst Rev 2013; 2013 (7): CD003099

[36] Knauß A, Strunz K, Wöckel A et al. Geburtseinleitung mit Rizinusöl - Ergebnisse der Ulmer Rizinus-Studie. Die Hebamme 2009; 22: 216-218

[37] National Institute for Health and Care Excellence. Inducing labor (NICE guideline CG70). 2008. Accessed September 10, 2019 at: https://www. nice.org.uk/Guidance/CG70

[38] Bossung V, Rath W, Rody A et al. Heterogenous use of misoprostol for induction of labour: results of an online survey among midwives in German-speaking countries. Arch Gynecol Obstet 2021. doi:10.1007/ s00404-021-06079-7 